\title{
EFFECT OF SOME BIOCIDES ON THE VASE LIFE OF CARNATION (DIANTHUS CARYOPHYLLUS L.) CUT FLOWERS
}

\author{
Amani I. Adam and Mona B. Eldeeb \\ Antoniadis Research Branch, Ornamental Plants and Landscape Gardening Res. Dept., Horticulture \\ Research Institute, ARC, Alexandria, Egypt
}

\begin{abstract}
The current study was carried out at Antoniades Research Branch, Ornamental Plants and Landscape Gardening Res. Dept., Hort. Res. Inst., ARC, Alexandria, Egypt, over two consecutive seasons of 2019 and 2020. The aim of this study was to compare the effects of silver nitrate $\left(\mathrm{AgNO}_{3}\right)$ at $\left(20,30\right.$, and $\left.40 \mathrm{mg} \mathrm{l}^{-1}\right)$, 8hydroxyquinoline sulfate (8-HQS) at $\left(50,100\right.$, and $\left.200 \mathrm{mg} \mathrm{l}^{-1}\right)$, citric acid (CA) at $\left(50,100\right.$, and $\left.150 \mathrm{mg} \mathrm{l}^{-1}\right)$ and salicylic acid (SA) at (100, 150 , and $200 \mathrm{mg} \mathrm{l}^{-1}$ ) as holding preservative solutions for reducing bacterial decay and prolonging the vase life on cut carnation (Dianthus caryophyllus L.) flowers. The following records were evaluated at the conclusion of the experiment: vase life (days), which was calculated as the number of days before the flowers started to wilt, loss of flower fresh weight percentage (LFFW percent), final water uptake (g), flower fresh weight/flower dry weight ratio (FWR), relative fresh weight, vase solution uptake rate, and several chemical component tests. The results showed that the highest significant improvement in most measurements were obtained when treated with silver nitrate $\mathrm{AgNO}_{3}$ at a concentration of $30 \mathrm{mg} \mathrm{l}^{-1}$ including improved vase life, final water uptake, flower fresh weight/flower dry weight ratio, chlorophyll a \& b, carotene content, and sugars content. It also reduced the number of bacterial colonies in the vase water. The treatment with 8-hydroquinoline sulfate at $200 \mathrm{mg} \mathrm{l}^{-1}$ was the closest to that treatment in most of the studied characteristics.
\end{abstract}

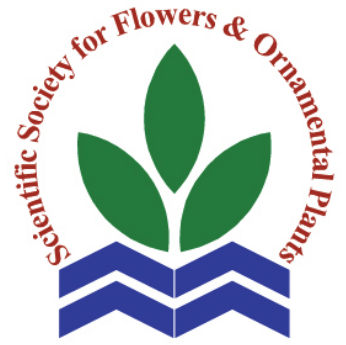

Scientific J. Flowers \& Ornamental Plants, 8(2):209-221 (2021).

Received:

22/3/2021

Accepted:

$2 / 5 / 2021$

Corresponding author: Amani I. Adam amaniadm@hotmail.com

Key words: vase life, citric acid, salicylic acid, 8-hydroxyquinoline sulfate, silver nitrate, carnation (Dianthus caryophyllus L.).

\section{INTRODUCTION}

The Caryophyllaceae Family includes carnation (Dianthus caryphyllus L.). The nursery carnation originated in the Mediterranean area. Carnations are among the top ten most common cut flowers in the world, mostly with the greatest value of the cut flower market for decor and ornament (Larson, 1992; Hashemabadi et al., 2015). The vase life of carnations varies between species and cultivars, and it is one of the most important factors in deciding consistency, fulfilling customer desires, and commercial value (Onozaki et al., 2001 and Nukui et al., 2004).
One of the really serious issues with cut flowers is their short postharvest vase life. The durability of vase life, on the other hand, is an important factor in customer choice (Kader, 2003). Weak water connections in cut flowers have been stated to be due to increased stem resistance to water movement microorganism activity in the vase solution. These issues have been addressed in different cut flowers by the use of biocides and low $\mathrm{pH}$ vase solutions (Nowak and Rundnicki, 1990). Keeping quality is a critical factor in determining the quality of cut flowers for both domestic and international markets. To extend the vase life 
of cut flowers, it is advised that chemical preservatives be added to the holding solution. Definite germicides must be present in all holding solutions. Germicides keep dangerous bacteria at bay and keep conducting tissues from being clogged. As a result, strategies for extending the vase life of cut flowers would be extremely beneficial to both farmers and consumers.

Silver nitrate $\left(\mathrm{AgNO}_{3}\right)$ has a well-known antimicrobial effect because $\mathrm{Ag}^{+}$ions replace hydrogen cations $\left(\mathrm{H}^{+}\right)$on surface proteins in bacterial cell membranes, resulting in membrane integrity loss and cell death (Feng et al., 2000). It is more effective as a biocide (Jiang et al., 2004). Pulsing cut roses using $\mathrm{AgNO}_{3}$ for 10 and 20 minutes increased vase life to 6.0 and 5.3 days, respectively (Reddy et al., 1988). When $\mathrm{AgNO}_{3}$ was applied, the vase life was risen exponentially, and the fresh weight gain increased compared to 5.3 days in the guide (Asrar, 2012). However, when compared to the control, it increased the rate of respiration of the leaves (Kofranek and paul, 1975). Also, Nair et al. (2003) investigated the impact of $\mathrm{AgNO}_{3}$ plus sucrose in various concentrations on the vase life of gerbera cut flower; the treatment prolonged the vase life, delayed head falling and discoloration, and increased vase life by 8.2 days.

8-hydroxyquinoline (8-HQ) is a common floral preservative that increases the long term survival of cut rose flowers (Tiwari and Singh, 2002). 8-HQ is very well for expanding flower vase life by preventing microbe's accumulation in xylem vessels, preserving water absorption, and extending flower vase life (Asrar, 2012). Elgimabi and Sliai (2013) reported that $200 \mathrm{mg} \mathrm{l}^{-1}$ of 8HQS as ethylene antagonist combined with $7 \%$ sucrose prolonged the vase life of Rosa damascena cv. Trigintipetala and delayed chlorophyll and carbohydrates decay.

Citric acid (CA) is a commonly used and commercially available acidifying agent that inhibits bacterial growth in the stem (Nowak \& Rudnicki, 1990). Citric acid was commonly used to lower the $\mathrm{pH}$ of water balance and avoid stem plugging, according to Halevy et al. (1978). Citric acid was found to have a beneficial effect on the survival of cut flowers. Water acidification, according to Durkin (1981), can increase vessel wall porosity by breaking the calcium pectate bonds. Using (CA) to vase solution reduces latex flow from the stem cut surface, delays xylem closure, preserves water equilibrium, and reduces bacteria growth in the vase solution, thereby preventing xylem vessel congestion (Imsabai et al., 2013; Capdeville et al., 2003). Furthermore, using citric acid (CA) at $0,100,200 \mathrm{mg} \mathrm{l}^{-1}$ significantly increased vase life, petal water content $(\%)$, initial fresh weight (\%) and marketability of chrysanthemum cut flowers (Vahdati et al., 2012).

Salicylic acid (SA) is a phenolic endogenous growth regulator; SA is a hormone-like substance that plays an essential part in controlling many biological activities and protects the plant from biotic and abiotic stresses. SA is naturally produced by plants as a secondary metabolite. SA is involved in many aspects of plant growth and production, including ethylene biosynthesis, stomatal conductance, respiration, and defense in various plants (Loutfy et al., 2012). SA plays an important role in plant defense and is involved in the activation of defense mechanisms against various pathogens (Grant and Lamb, 2006). SA at different ratios have increased the vase life of Gerbera (Kazemi et al., 2011a) and lily cut flowers (Kazemi et al., 2011b). According to Ezhilmathi et al. (2007), different salicylic acid concentrations can reduce cell death, prolong vase life, and improve vase life-related properties in gladiolus (Gladiolus grandiflora).

The aim of this study is to see how various concentrations of bactericides and preservative solutions, such as 8hydroxyquinoline sulfate (8-HQS), citric acid (CA), salicylic acid (SA), and silver nitrate $\left(\mathrm{AgNO}_{3}\right)$, affect bacterial life exhaustion and vase life of cut carnation flowers (Dianthus caryophylus 'Mirella'). 


\section{MATERIALS AND METHODS}

The present study was conducted at Antoniades Research Branch, Ornamental Plants and Landscape Gardening Res. Dept., Hort. Res. Inst., ARC, Alexandria, Egypt during the two successive seasons of 2019 and 2020. The bacterial studies were done at the laboratory of Bacterial Plant Diseases and Molecular Bacteriology, Faculty of Agriculture, El-Shatby, Alexandria University, Egypt.

\section{Plant materials:}

Cut flowers (Dianthus caryophylus 'Mirella') were obtained from a well-known commercial nursery in Alexandria, Egypt. Cut carnations were harvested in early morning, at the early stage of flower opening when the outer petals converted vertical to the stem axis (Dole and Wilkins, 1999; Pun et al., 2014). They were wrapped using polyethylene then quickly transported to the laboratory.

The experimental work procedures were as follows; on the February $1^{\text {st }} 2019$ and 2020 (in the first and second seasons, respectively) flowers were transplanted to the laboratory under dry conditions, the stems of cut flowers were recut to a length of $40 \mathrm{~cm}$ under distilled water before applying pulsing treatments. The lower leaves were removed to avoid contamination in the vase solution.

\section{The following treatment were applied:}

Thirteen treatments were applied in this experiment. Cut flowers were held in glass jars containing $400 \mathrm{ml}$ of distilled water containing $20 \mathrm{~g} / \mathrm{l}$ sucrose added to all treatments of the following solutions.

1. Distilled water (control).

2. $\mathrm{AgNO}_{3}$ at 20,30 and $40 \mathrm{mg} \mathrm{l}^{-1}$.

3. Citric acid (CA) at 50, 100 and $150 \mathrm{mg} \mathrm{l}^{-1}$.

4. Salicylic acid (SA) at 100, 150 and 200

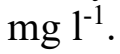

5. 8-hydroxyquinoline sulfate (8-HQS) at 50,100 and $200 \mathrm{mg} \mathrm{l}^{-1}$.

\section{Lab conditions:}

The cut flowers were remained at the average temperature of $\left(18.6-19^{\circ} \mathrm{C}\right)$, average humidity $(63 \%-65 \%)$ and 24 hours fluorescent light (about 450- 500 lux).

Experimental layout and statistical analysis:

The experimental layout was a completely randomized design (CRD). It consists of thirteen treatments with three replicates, each replicate contained three flowers. The means of the individual factors were compared by L.S.D. test at 5\% level of probability. Data were statistically analyzed according to the method described by Snedecor and Cochran (1989).

Data were recorded as the following:

The postharvest characters:

1. Vase life (days):

It was determined as the number of days from starting the experiment to the fading stage. The fading stage was set at the wilting of $50 \%$ of petals or browning or inward rolling (Karimian and Tehranifar, 2011; Pun et al., 2014).

\section{Loss of flower fresh weight percentage (LFFW\%):}

It was determined at the fading stage as the following formula:

$$
\text { LFFW }(\%)=\frac{\begin{array}{c}
\text { Initial fresh weight }- \text { final } \\
\text { fresh weight }
\end{array}}{\text { Initial fresh weight }} \times 100
$$

\section{Final water uptake (g):}

It was calculated at the end of the experiment using the following formula:

Water uptake $(\mathrm{g})=$ The amount of solution at the beginning of the experiment - the amount of the solution remaining at the end of the experiment.

\section{Flower fresh weight/flower dry weight ratio (FWR):}

At the fading stage the cut flowers were oven dried at $75{ }^{\circ} \mathrm{C}$ for 48 hours to get the 
dry weight (F.D.W.). The fresh weight was divided by the dry weight as below:

FWR $=\frac{\text { Fresh weight } / \text { flower }(\mathrm{g})}{\text { Dry weight } / \text { flower }(\mathrm{g})}$

\section{Relative fresh weight (RFW):}

Fresh weight of the flowers was determined just before the immersion of the flowers into the solutions and collected every two days until the vase life of the flowers was terminated. The fresh weight of each flower was expressed relative to the initial weight to represent the water status of the flower.

Relative fresh weight $(\mathrm{RFW})(\%)=\frac{\mathrm{Wt}}{\mathrm{W} 0} \times 100$

Where Wt is the weight of flower (g) at (2, 4 and 6 days), W0 is the initial fresh weight of the same flower $(\mathrm{g})$.

\section{Vase solution uptake rate:}

The VSU rate was measured according to the formula below:

VSU rate $=\frac{(\text { St-1 })-\text { St }}{\text { IFW of stem }} \times 100$

Where (St) is weight of vase solution $(\mathrm{g})$ at (2, 4 and 6 days), (St-1) is the weight of the vase solution $(\mathrm{g})$ on the previous day and (IFW) is the initial fresh weight (g).

\section{Chemical analysis:}

Chlorophyll $\mathrm{a}$ and $\mathrm{b}$ contents $\left(\mathrm{mg} \mathrm{g}^{-1}\right.$ fresh weight) were determined in the leaves according to Moran (1982) and total carotene in flowers (mg $100 \mathrm{~g} \mathrm{~g}^{-1}$ fresh weight) according to Wellburn (1994) and reducing sugars content ( $\mathrm{mg} \mathrm{g}^{-1}$ dry weight) according to Miller (1959) at the end of the vase life of the control.

\section{Average bacterial counts (C.F.U/ml):}

Solutions $(0.1 \mathrm{ml})$ were spread on general medium (nutrient agar), incubated for $24 \mathrm{~h}$ at $29{ }^{\circ} \mathrm{C}$ and were evaluated by serial dilutions. Number of colonies per petri dish was counted accurately. All bacteria counting was replicated three times (Balestra et al., 2005).

\section{RESULTS}

\section{The postharvest characters:}

\section{Vase life (days):}

Data presented in Table (1) show that holding the flowers in all preservative solutions for two seasons significantly improved vase life compared to holding the flowers in distilled water (control). Furthermore, the highest significant values of flower vase life were reported for flowers deposited in an $\mathrm{AgNO}_{3}$ solution at $30 \mathrm{mg} \mathrm{l}^{-1}$, which were (16.37 and 16.85 days) in both seasons. It was followed by application with $8 \mathrm{HQS}$ at $200 \mathrm{mg} \mathrm{l}^{-1}$ which recorded 14.33 and 15.52 days in both seasons, respectively.

Furthermore, the application of 100 $\mathrm{mg} \mathrm{l}^{-1}$ of SA resulted in the shortest vase life as holding solution, which registered 10.22 and 9.74 days in both seasons. After untreated flowers, which it still got the shortest significant vase life (8.04 and 7.67 days), respectively.

\section{Loss of flowers fresh weight percentage (LFFW\%):}

Results in Table (1) show that the lowest significant decrees in LFFW ratio was obtained after $\mathrm{AgNO}_{3}$ at $30 \mathrm{mg} \mathrm{l}^{-1}$, the final fresh weight of this treatment was more than the initial fresh weight by 13.78 and $11.95 \%$ in the both seasons, respectively. Alternatively, the highest increase in LFFW was obtained after application of SA at 100 $\mathrm{mg}^{-1}$ which recorded 36.69 and $33.72 \%$ less than the initial fresh weight in both seasons, respectively.

\section{Final water uptake (g/plant):}

Data exhibited in Table (1) cleared that the largest raise (116.42 and $113.9 \mathrm{~g})$ in the $1^{\text {st }}$ and $2^{\text {nd }}$ seasons with the use of $\mathrm{AgNO}_{3}$ at $30 \mathrm{mg}^{-1}$. It was followed by application with $\mathrm{AgNO}_{3}$ at $40 \mathrm{mg} \mathrm{l}^{-1}$ (108.16 and 106.16 g). The same table also showed that the smallest amount of water uptake in the first and second seasons was measured after SA at $100 \mathrm{mg} \mathrm{l}^{-1} 64.81$ and $56.03 \mathrm{~g}$ respectively. 
Table 1. Means of vase life (days), loss of flower fresh weight (LFFW), final water uptake (g) and flower fresh weight/dry weight ratio (FWR) of Dianthus caryophyllus as affected by different concentrations of some biocides preservative solutions in two seasons.

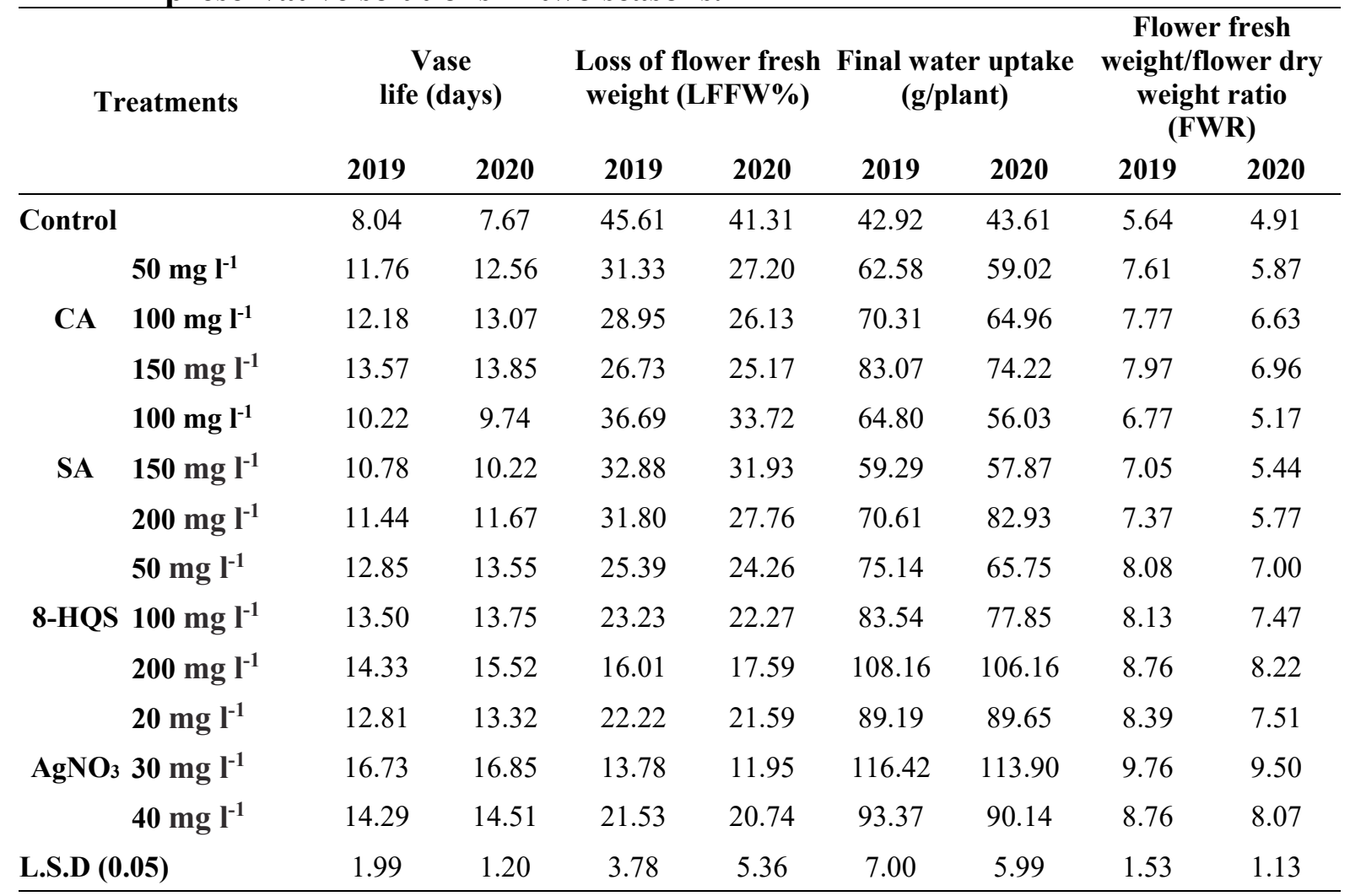

CA: citric acid, SA: salicylic acid.

\section{Flower fresh weight / flower dry weight ratio (FWR):}

Table (1) shows that the highest increase in flower fresh weight/flower dry weight ratio was obtained following application of $\mathrm{AgNO}_{3}$ at $30 \mathrm{mg} \mathrm{l}^{-1}$ in both seasons $(9.76$ and $9.50 \%$ ). In the $1^{\text {st }}$ and $2^{\text {nd }}$ seasons of the SA procedure, on the contrary, $100 \mathrm{mg} \mathrm{l}^{-1}$ gave the smallest FWR ratio (6.77 and $5.17 \%)$.

\section{Relative fresh weight (RFW):}

Data presented in Fig. (1) reveal the RFW value after the second, fourth, and sixth days of the experiment. According to the table, adding $\mathrm{AgNO}_{3}$ at $30 \mathrm{ppm}$ and 40 ppm resulted in the highest RFW values of 2 , 4 , and 6 days $(119.81,93.97,83.33$ and $123.15,97.6,80.56)$ after research had begun in both seasons, with the same level of significance. Despite this, the implementation of SA at $100 \mathrm{ppm}$ caused the smallest RFW after 2, 4, and 6 days (96.06, $63.81,51.77$ and 90.87, 64.46, 51.13) after the experiment had begun. The untreated plants had the lowest RFW. When the vase life of the control plants began to shorten, the RFW value of all treatments began to fall (Fig., 1).

\section{Vase solution uptake (\%):}

In both seasons, control plants had the lowest VSU value when compared to other treatments, as shown in Fig. (2). Furthermore, on the $2^{\text {nd }}$ record after six days of experiment, the vase living of the untreated plants was terminated. On sixth day of the experiment, the VSU value of all $\mathrm{AgNO}_{3}$ treatments and 8-HQS with greater than that recorded on the $2^{\text {nd }}$ day of the experiment, whereas the other chemicals recorded edicts in the VSU value when 


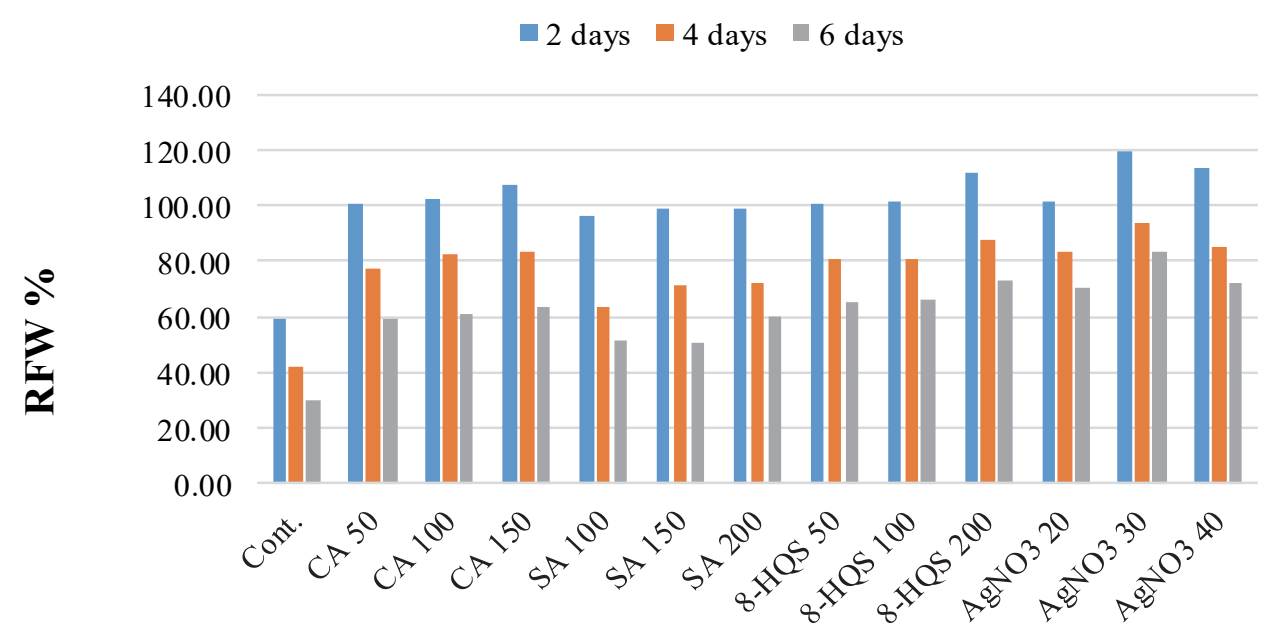

2019

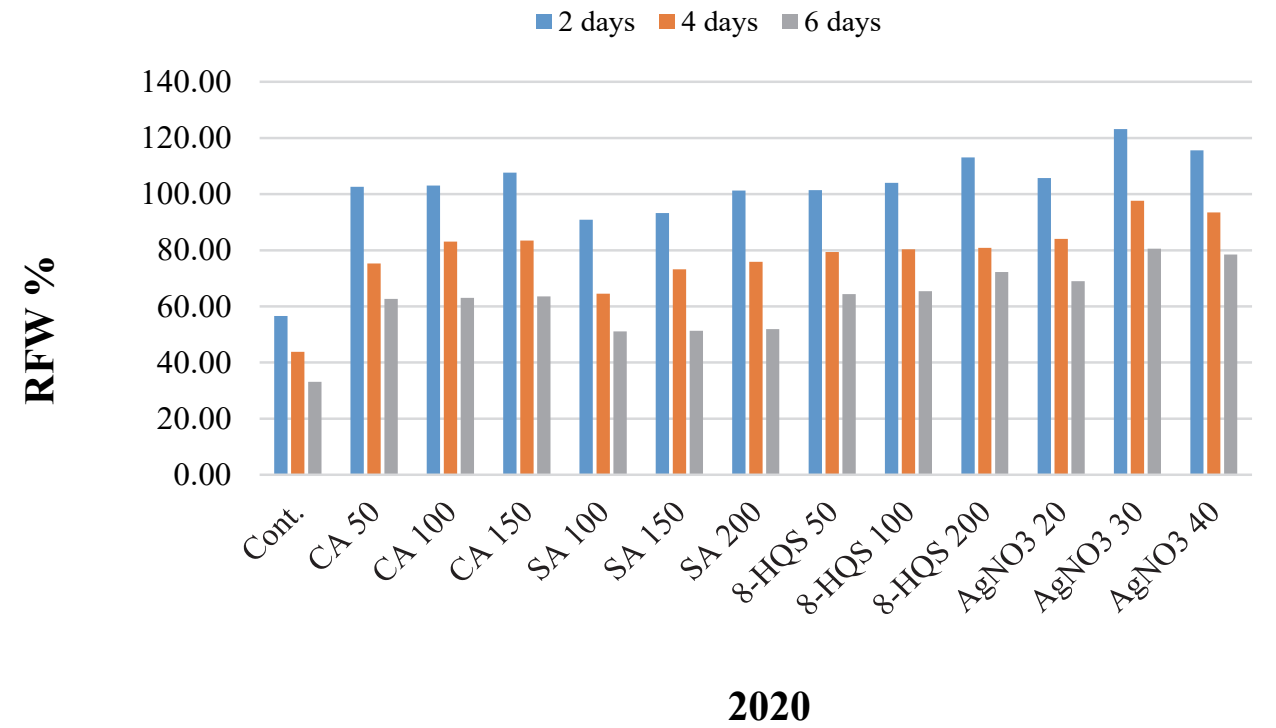

Fig. 1. Effect of the different biocides concentrations on relative fresh weight (RFW \%) of Dianthus caryophyllus through the experiment period during the seasons of 2019 and 2020.

compared to prior value recorded on the second day of the experiment. After 6 days of the experiment, there was a clear decrease in the VSU value for all treatments, and a noticeable decrement in VSU value was recorded for all treatments.

\section{The chemical characters:}

1. Chlorophyll a, b ( $\mathrm{mg} \mathrm{g}^{-1}$ fresh weight) and carotene ( $\mathrm{mg} 100 \mathrm{~g}^{-1}$ fresh weight):

Data exhibited in Table (2) revealed a significant difference in chlorophyll $\mathrm{a}, \mathrm{b}$ and carotenoids content after utilizing various treatments. After adding $\mathrm{AgNO}_{3}$ at $30 \mathrm{mg} \mathrm{l}^{-1}$, the maximum chl. $\mathrm{a}, \mathrm{b}$ and carotene content was determined. At the same time, untreated plants had the lowest chl. a, b and carotene content in both seasons.

2. Reducing sugars content $\mathrm{mg} \mathrm{g}^{-1}$ dry weight:

Table (2) cleared that there was a significant reduction of sugar content after using different treatments. 


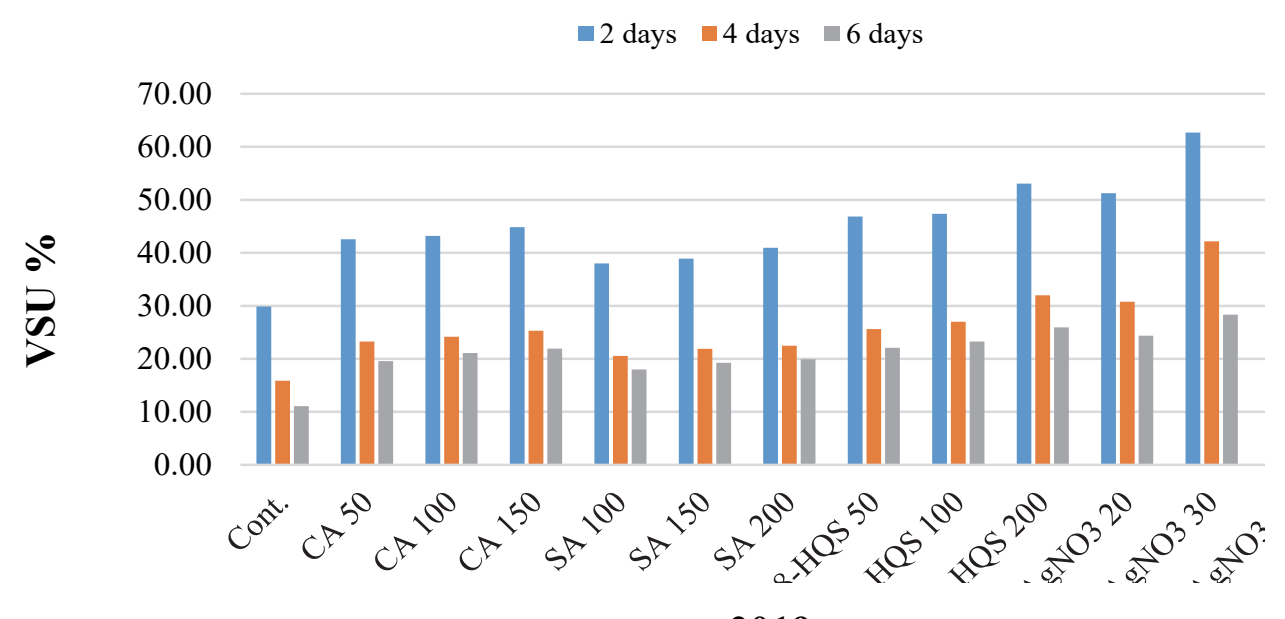

2019

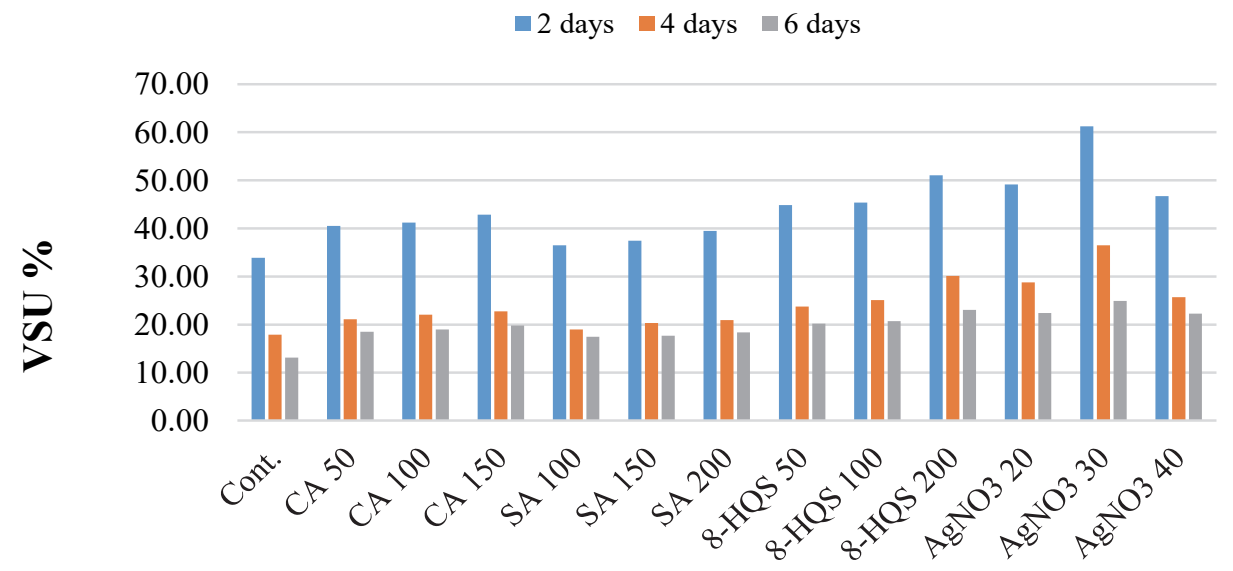

2020

Fig. 2. Effect of the different biocides concentrations on vase solution uptake (VSU \%) of of Dianthus caryophyllus through the experiment period during the seasons of 2019 and 2020.

The highest reduction of sugar content (9.26 and 9.19) in both seasons, respectively was obtained from using $\mathrm{AgNO}_{3}$ at $30 \mathrm{mg} \mathrm{l}^{-}$ 1 . While, the lowest reduction of sugar content was obtained after using SA at 100 $\mathrm{mg}^{-1}\left(5.97\right.$ and $\left.6.20 \mathrm{mg} \mathrm{g}^{-1} \mathrm{dw}\right)$ in both seasons. Also, data showed that the lowest significant reduction sugar content was obtained for untreated spicks. Regarding the interaction of the use of chemical and its concentrations, applying $\mathrm{AgNO}_{3}$ at $30 \mathrm{mg} \mathrm{l}^{-1}$ and $8 \mathrm{HQS}$ at $200 \mathrm{mg} \mathrm{l}^{-1}$ caused the highest significant increase in reducing sugar content.

\section{Number of bacterial colonies:}

After different treatments, data presented in Figs. (3) and (4) showed a substantially different number of bacterial colonies. Most bacterial colonies were found in the control treatment. Both treatments resulted in a substantial decrease in the number of bacterial colonies. The use of $\mathrm{AgNO}_{3}$ at 30 ppm resulted in a highly important decrease 
Table 2. Means of Chlorphyll a and $b$, carotenoids and reducing sugar content of Dianthus caryophyllus as affected by different concentrations of some biocides preservative solutions in two seasons.

\begin{tabular}{|c|c|c|c|c|c|c|c|c|c|}
\hline \multicolumn{2}{|c|}{ Treatments } & \multicolumn{2}{|c|}{$\begin{array}{l}\text { Chlorophyll a } \\
\text { (mg g-1 f.w.) }\end{array}$} & \multicolumn{2}{|c|}{$\begin{array}{l}\text { Chlorophyll b } \\
\text { (mg g }{ }^{-1} \text { f.w.) }\end{array}$} & \multicolumn{2}{|c|}{$\begin{array}{c}\text { Carotene } \\
\left(m g 100 \mathrm{~g}^{-1} \text { f.w.) }\right.\end{array}$} & \multicolumn{2}{|c|}{$\begin{array}{l}\text { Reducing sugar } \\
\left(\mathrm{mg} \mathrm{g}^{-1} \text { d.w. }\right)\end{array}$} \\
\hline & & 2019 & 2020 & 2019 & 2020 & 2019 & 2020 & 2019 & 2020 \\
\hline \multirow[t]{2}{*}{ Control } & & 6.66 & 7.64 & 2.40 & 2.39 & 4.01 & 4.17 & 5.13 & 5.21 \\
\hline & $50 \mathrm{mg} \mathrm{l}^{-1}$ & 12.20 & 10.18 & 5.03 & 7.70 & 4.37 & 5.51 & 5.42 & 5.56 \\
\hline \multirow[t]{3}{*}{$\mathbf{C A}$} & $100 \mathrm{mg} \mathrm{l}^{-1}$ & 13.91 & 13.78 & 3.28 & 5.96 & 5.46 & 5.96 & 5.63 & 5.78 \\
\hline & $150 \mathrm{mg} \mathrm{l}^{-1}$ & 12.46 & 13.66 & 4.06 & 6.89 & 6.39 & 7.24 & 5.80 & 6.09 \\
\hline & $100 \mathrm{mg} \mathrm{l}^{-1}$ & 15.14 & 12.94 & 4.04 & 4.14 & 6.35 & 6.38 & 5.97 & 6.20 \\
\hline \multirow[t]{3}{*}{ SA } & $150 \mathrm{mg} \mathrm{l}^{-1}$ & 15.13 & 15.19 & 5.29 & 5.19 & 5.80 & 5.79 & 6.36 & 6.44 \\
\hline & $200 \mathrm{mg} \mathrm{l}^{-1}$ & 15.55 & 15.30 & 3.12 & 6.16 & 6.59 & 6.45 & 6.70 & 6.86 \\
\hline & $50 \mathrm{mg} \mathrm{l}^{-1}$ & 14.07 & 14.85 & 4.59 & 4.76 & 6.74 & 6.75 & 7.83 & 7.19 \\
\hline \multirow[t]{3}{*}{ 8-HQS } & $100 \mathrm{mg} \mathrm{l}^{-1}$ & 15.05 & 14.01 & 4.99 & 6.30 & 6.60 & 7.66 & 8.07 & 7.64 \\
\hline & $200 \mathrm{mg} \mathrm{l}^{-1}$ & 11.97 & 11.88 & 4.11 & 6.80 & 7.46 & 8.15 & 8.42 & 7.96 \\
\hline & $20 \mathrm{mg} \mathrm{l}^{-1}$ & 15.80 & 15.70 & 5.36 & 6.79 & 7.38 & 8.64 & 8.61 & 8.27 \\
\hline \multirow[t]{2}{*}{$\mathrm{AgNO}_{3}$} & $30 \mathrm{mg} \mathrm{l}^{-1}$ & 17.08 & 16.64 & 3.81 & 8.13 & 8.63 & 9.53 & 9.26 & 9.19 \\
\hline & $40 \mathrm{mg} \mathrm{l}^{-1}$ & 17.82 & 15.23 & 5.33 & 7.29 & 6.68 & 7.87 & 8.76 & 8.65 \\
\hline \multicolumn{2}{|c|}{ L.S.D (0.05) } & 3.52 & 2.21 & 2.08 & 1.95 & 0.74 & 1.89 & 0.35 & 0.57 \\
\hline
\end{tabular}

CA: citric acid, SA: salicylic acid.

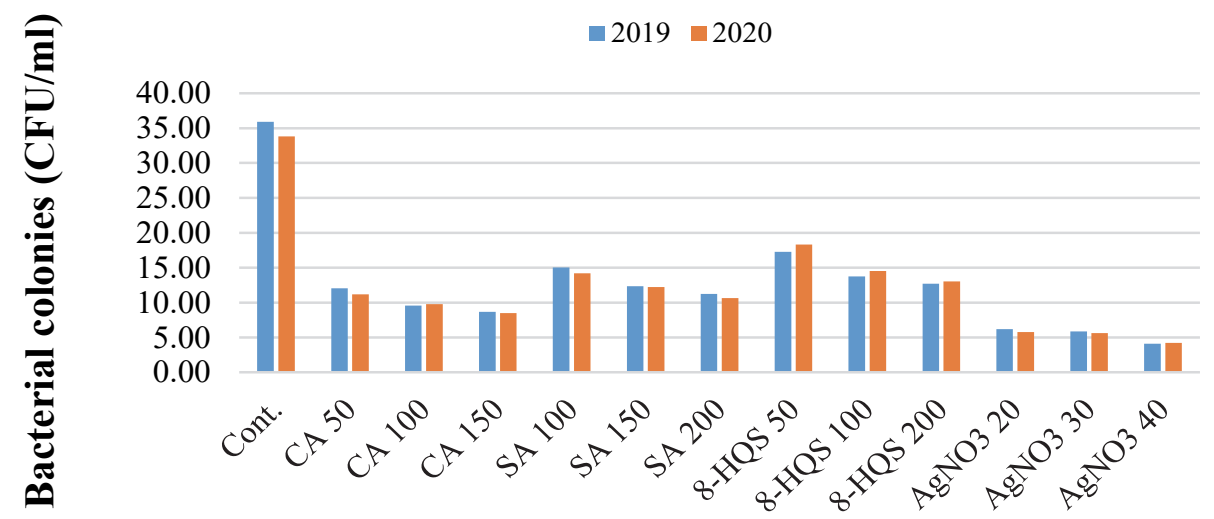

Fig. 3. Effect of the different biocides concentrations on number of bacterial colonies $(\mathrm{CFU} / \mathrm{ml})$ through the experiment period during the seasons of 2019 and 2020. 


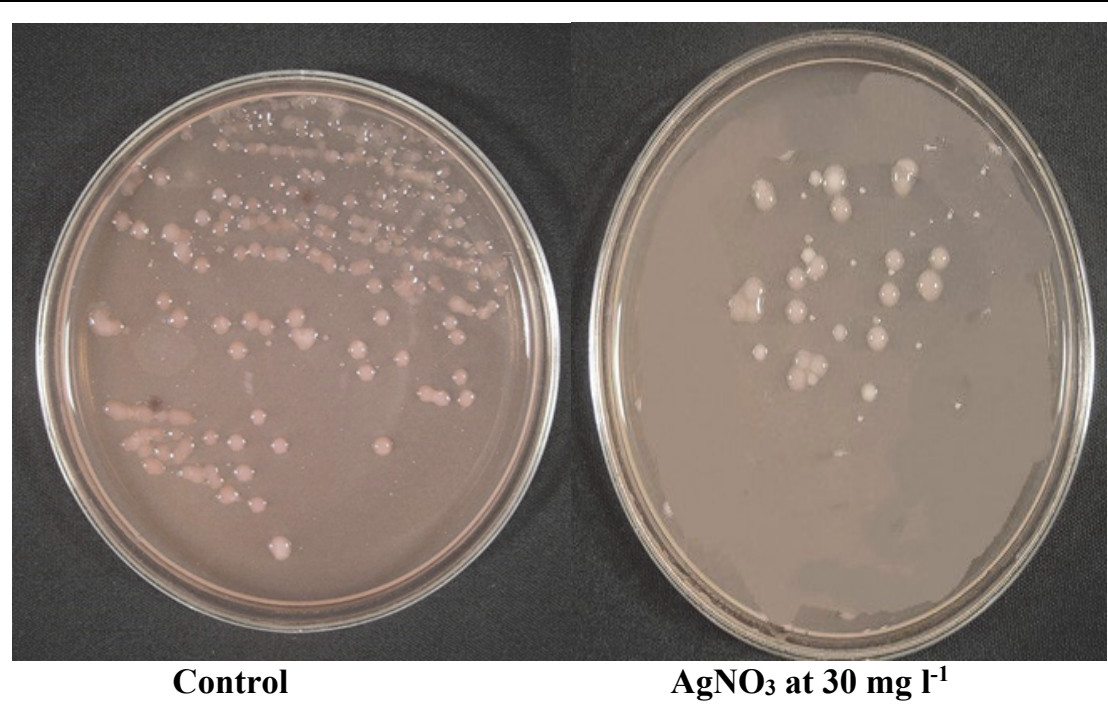

Fig. 4. Pattern of bacterial abundance in vase solution on $\mathrm{NA}$ media treated with $\mathrm{AgNO}_{3}$ $30 \mathrm{mg} \mathrm{l}^{-1}$ as compared to the control (distilled water).

in the number of bacterial colonies. The highly significant reduction was achieved by utilizing $\mathrm{AgNO}_{3}$ at $30 \mathrm{mg} \mathrm{l}^{-1}$, that was registered $(4.10$ and $4.23 \mathrm{CFU} / \mathrm{ml})$ in both seasons, and the poorest with treatments of SA at 100 ppm gave 17.26 and 18.33 $\mathrm{CFU} / \mathrm{ml}$ for both seasons, respectively.

\section{DISCUSSION}

The length of flower vas life has economic implication. The shorter life of the vase could be a number of factors, including climatic ethylene synthesis (Halevy and Mayak, 1981) due to blockage of the xylem vessels by the products of decomposing bacterial products (VanDoorn, 1997).

Some of chemicals tested for prolonging vase life are inhibitors of ethylene synthesis, such as silver (Veen and Van de Geijn,1978), and exhibit antimicrobial action such as salicylic acid, acetylsalicylic acid and hydroxyquinoline (VanDoorn,1997).

These chemicals are known to suppress microbial activity and they are usually employed in this context (VanDoorn,1997) (Petridou and Voyiatzis, 1999).

In the present study results showed that the bacteria populations in the vase solution was highest in the control treatment and lowest in the treatments of each $\mathrm{AgNO}_{3}$ at 30 (Fig., 4) and $200 \mathrm{mg} \mathrm{l}^{-1}$ of 8 -HQS. These results are consistent with (Rad, 2018) who concluded that treatment of 8-HQS (400 mg $\left.1^{-1}\right)$ gave the highest vase life. Silver, applied as silver nitrate $(2 \mathrm{mM})$ passes up the stems of cut carnations (Dianthus caryophyllus L.) at a rate of about $3 \mathrm{~cm} /$ day.

In the control treatments, number of bacteria rapidly increased in the stem end of solidago, however treating with $200 \mathrm{mg} \mathrm{l}^{-1} 8$ hydroxy quinoline sulphate inhibits the rise in the bacteria population, causing an increase in water absorption and significantly increasing their survival (Ichimura et al., 1999).

Fresh weight loss is primarily determined by two factors: water absorption and transpiration. At high concentrations, 8HQS with antibacterial properties improves water absorption by minimizing microorganism colonization and, as a result, increases fresh weight (Ichimura et al., 2002). 8-HQC has significant germicidal effects that promote water absorption and prevent stem end blockage (Ichimura et al., 1999), and these findings are consistent with ours. 
$\mathrm{AgNO}_{3}$ treatment at $30 \mathrm{ppm}$ induces very little fresh weight loss in cut flowers. According to this study; stem end blockage is formed by the action of microorganisms such as bacteria. Microorganisms manufacture ethylene and produce toxic metabolites, and the use of antimicrobial compounds prevents the growth and accumulation of bacteria, thus improving hydraulic conductivity (Halevy and Mayak, 1981).

The increase in the life expectancy of the flowers, even after a brief application of a complex silver-thiosulphate solution, indicates that silver's anti-ethylene effect is not lost by adding silver in that form. Following $24 \mathrm{~h}$ treatment with the silver thiosulfate in the nearby area of the vascular system, complex a microscopic receptacle observation indicates a blackening. The silver thiosulphate complex is therefore likely to dissociate and free silver so as to act efficiently as an anti-ethylene agent.

A preservative solution containing 30 $\mathrm{mg} / \mathrm{l} \mathrm{AgNO}_{3}$ produced the longest vase life of 16 days, followed by holding in preservative solutions containing $200 \mathrm{mg} / \mathrm{l}$ 8HQS.

Both had a subsequent vase life of 14 days. Applying treatments significantly increase carnation vase life compared to control treatment. The results of this survey were in agreement with (Torre et al., 2002) who described that $\mathrm{CaCl}_{2}$ treatment successfully led to improving bud opening, hindering both membrane proteins and phospholipids reduction and increasing ATPase activity in rose petals during senescence.

In the same way, cut Gerbera hybrid flower shield in $\mathrm{CaCl}_{2}$ preservative solution resulted in extending its vase life (Chen et al., 2004). Considering the results of this survey, it is hypothesized that the biological activity in carnation stem or vase solution, which causes xylem blockage and increases ethylene content, is extremely sensitive to 8HQS at $125 \mathrm{mg} \mathrm{l}^{-1}$ (Omid et al., 2014)
At these concentrations, 8-HQS with antibacterial properties improves water absorption by minimizing microorganism colonization and, as a result, increases fresh weight (Ichimura et al., 2002). 8-HQS has significant germicidal effects that promote water absorption and prevent stem end blockage (Ichimura et al., 1999), which is consistent with our findings. The reason for the superiority of the antimicrobial or antiethylene compounds can be preventing the activity of chlorophyllase enzyme and not breaking down chlorophyll in old leaves (Basiri and Zarei, 2011).

Quinoline esters and 8-HQS can inhibit stem plugging by decreasing the solution $\mathrm{pH}$. Their capacity to minimize vascular blockage may be attributed to their ability to inactivate enzyme systems by means of $\mathrm{pH}$ modification. Only the $8-\mathrm{HQ}$ is able to chelate metallic ions of seven isomeric mono-HQs and is also the only HQ that is antibacterial. (Edrisi et. al., 2011).

When the vase life of the control plant had expired, the most important increase in reducing sugar content was observed after the application of $\mathrm{AgNO}_{3}$ at $30 \mathrm{mg} \mathrm{l}^{-1}$. This increment could well raise the osmolality capacity of the flowers, enhancing their uptake of nutrients and sustain turgidity, which could explain the increase in flower longevity observed in this study (Prathamesh and John, 2013). In general, cut stem held in distilled water experienced water stress early, which might be due to disruption of water column in the flower stem (Rogers, 1973).

\section{CONCLUSION}

Finally, it could be recommended to use AgNO3 at $30 \mathrm{mg} / \mathrm{l}$ as a holding preservation solution to complete their shelf life period in the case of cut carnation flowers (Dianthus caryophylus 'Mirella') at the normal commercial harvest stage. This treatment caused increment of the flower vase life ( 16.73 and 16.85 days) by $120 \%$ more than control plants (8.04 and 7.67 days), increase in final water uptake, chlorophyll $a$ and $b$ 
contents and decrease number of bacterial colonies in vase solution.

\section{REFERENCES}

Asrar, A.W.A. (2012). Effects of some preservative solutions on vase life and keeping quality of snapdragon (Antirrhinum majus L.) cut flowers. Journal of the Saudi Society of Agricultural Sciences,11(1):29-35.

Balestra, G.M.; Agostini, R.; Bellincontro, A.; Mencarelli, F. and Varvaro, L. (2005). Bacterial populations related to gerbera (Gerbera jamesonii, L.) stem break. Phytopathol. Mediterr., 44:291299.

Basiri, Y. and Zarei, H. (2011). Effects of nanosilver on longevity and some qualitative traits of cut carnation. Proceedings of $7^{\text {th }}$ Iranian Horticultural Science Congress, Isfahan University of Technology, 5-8 Sep.

Capdeville, G.de.; Maffia, L.A.; Finger, F.L. and Batista, U.G. (2003). Gray mold severity and vase life of rose buds after pulsing with citric acid, salicylic acid, calcium sulfate, sucrose and silver thiosulfate. Fitopatologia Brasileira, 28(4): 380-385.

Chen, D.S.; Li, N.H.; Wang, J.M.; Ding, Y.X. and Wang, X.J. (2004). Effect of calcium chloride on preservation of cut flowers of Gerbera hybrida. Acta Botanic Yunnanica, 26(3):345-348.

Dole, J.M. and Wilkins, H.F. (1999). Floriculture: principles and species. Prentice Hall Pub, Washington. Biol. and Tech., 79:32-38.

Durkin, D. (1981). Factors affecting hydration of cut flowers. Acta. Hort., 113:109-114.

Edrisi, B.; Sadrpoor, A. and Saffari, V.R. (2011). Effects of chemicals on vase life of cut carnation (Dianthus caryophyllus L. 'Delphi') and microorganisms population in solution. Journal of
Ornamental and Horticultural Plants, 2(1):1-11.

Elgimabi, M.N. and Sliai, A.M. (2013). Effects of preservative solutions on vase life and postharvest qualities of taif rose cut flowers (Rosa damascene 'Trigintipetala'). American-Eurasian J. Agric. \& Environ. Sci., 13(1):72-80.

Ezhilmathi, K.; Singh, V.P.; Arora, A. and Sairam, R.K. (2007). Effect of 5sulfosalicylic acid on antioxidant activity in relation to vase life of Gladiolus cut flowers. Plant Growth Regulation, 51: 99-108.

Feng, Q.L.; Wu, J.; Chen, G.Q.; Cui, F.Z.; Kim, T.N. and Kim, J.O. (2000). A mechanistic study of the antibacterial effect of silver ions on Escherichia coli and Staphylococcus aureus. Journal of biomedical materials research, 52(4): 662-668.

Grant, M. and Lamb, C. (2006). Systemic immunity. Current Opinion in Plant Biology, 9:414-420.

Halevy, A.H.; and Mayak, S. (1981). Senescence and postharvest physiology of cut flower, Part 2. Hort. Rev., 3:59143.

Halevy, A.H.; Byrne, T.G.; Kofranek, A.M.; Farnham, D.S.; Thompson, J.F. and Hardenburg, R.E. (1978). Evaluation of post-harvest handling methods for transcontinental truck shipments of cut carnations, chrysanthemums and roses. J. Amer. Soc. Hort. Sci., 103(2):151-155.

Hashemabadi, D; Kaviani, B.; Shirinpour, A. and Yaghoobi, D. (2015). Response of cut carnation (Dianthus caryophllus L.cv. Tempo) to essential oils and antimicrobial compounds. Int. J. Biosci., 6:636-644.

Ichimura, K.; Kamwabata, Y.; Kishmoto, M.; Goto, R. and Yamado, K. (2002). Variation with cultivar in the vase life of cut flowers. Bulletin of the National Institute of Floricultural Science, 2:9-20. 
Ichimura, K.; Kojima, K. and Goto, R. (1999). Effect of temperature, 8-hydroxy quinoline sulphate and sucrose on the vase life of cut rose flower. Postharvest Biology and Technology, 15(1):33-40.

Imsabai, W.; Leethiti, P.; Netlak, P. and Van Doorn, W.G. (2013). Petal blackening and lack of bud opening in cut lotus flowers (Nelumbo nucifera): role of adverse water relations. Biol. and Tech., 79:32-38.

Jiang, H.; Manolache, S.; Wongand, A.C.L. and Denes, F.S. (2004). Plasmaenhanced deposition of silver nanoparticles onto polymer and metal surfaces for the generation of antimicrobial characteristics. J. Appl. Polym. Sci., 93:1411- 1422.

Kader, A.A. (2003). A perspective on postharvest horticulture (1978-2003). Hort. Science, 38:1004-1008.

Karimian, F.Z. and Tehranifar, A. (2011). Effect of essential oils, ethanol and methanol to extend the vase-life of carnation (Dianthus caryophyllus L.) flowers. J. Biol. Environ. Sci., 5:91-94.

Kazemi, M.; Aran, M. and Zamani, S. (2011b). Extending the vase life of lisianthus (Eustoma grandiflorum Mariachii cv. Blue) with different preservatives. Am. J. plant physiol., 6:167-175.

Kazemi, M.; Hadavi, E. and Hekmati, J. (2011a). Role of salicylic acid in decreases of membrane senescence in cut carnation flowers. Am. J. Plant Physiol., 6:106-112.

Kofranek, A.M. and Paul, J.L. (1975). The value of impregnating cut stems with high concentrations of silver nitrate. Acta Hort., 41:199-206.

Larson, R.A. (1992). Introduction to Floriculture. $2^{\text {nd }}$ Edition. Academic Press INC, London, 636 p.

Loutfy, N.; El-Tayeb, M.A.; Hassanen, A.M.; Moustafa, M.F.M.; Sakuma, Y. and Inouhe, M. (2012). Changes in the water status and osmotic solute contents in response to drought and salicylic acid treatments in four different cultivars of wheat (Triticum aestivum). J. Plant Res., 125:173-184.

Miller, G.L. (1959). Use of dinitrosalicylic acid reagent for determination of reducing sugar. Anal. Chem., 31(3):426428.

Moran, R. (1982). Formula for determination of chlorophyll pigment extracted with $\mathrm{N}$, $\mathrm{N}$ diethyl formamide. Plant Physiology, 69:1376-1381.

Nair, S.A.; Singh, V. and Sharma, T.V.R.S. (2003). Effect of chemical preservatives on enhancing vase life of gerbera flowers. J. Tropical Agri., 41:56-58.

Nowak, J. and Rudnicki, R. (1990). Postharvest Handling and Storage of Cut Flowers, Florist Greens and Potted Plants. Timber Press, Inc., Oregon, USA, $210 \mathrm{p}$.

Nukui, H.; Kudo, S.; Yamashita, A. and Satoh, S. (2004). Repressed ethylene production in the gynoecium of longlasting flowers of the carnation 'White Candle': role of gynoecium in carnation flower senescence. J. Exp. Bot., 55: 641650 .

Omid, A.K.; Mehrdad, J. and Haana, M. (2014). Effects of preservative solutions on improving vase life of cut carnation flower. Proc. The $1^{\text {st }}$ International Conference on New Ideas in Agriculture Islamic Azard University Khoasgan Branch 26-27 Jan., Isfahan, Iran.

Onozaki, T.; Hiroshil, k. and Takashi, Y. (2001). Genetic improvement of vase life of carnation flowers by crossing and selection. Scientia Horticulturae, 87(1-2): 107-120.

Petridou, M.; Voyiatzi, Ch. and Voyiatzis, D. (1999). Aspirin, methanol and some antibacterial compounds prolong the vase life of cut carnations. Adev. Hort. Sci., 13:161-164. 
Prathamesh, V. and John, P.C. (2013). Effect of biocides and sucrose on vase life and quality of cut gerbera (Gerbera jamesonii) cv. Maron Dementine. HortFlora Research Spectrum, 2:239243.

Pun, U.K.; Yamada, T.; Tanase, K.; Shimizu, Y.H.; Satoh, S. and Ichimur, K. (2014). Effect of ethanol on ethylene biosynthesis and sensitivity in cut carnation flowers. Postharvest BioTechnology, 98:30-33.

Rad, D.H. (2018). Evaluation of cut carnation longevity cv. Yellow Candy under treatment with chemical and organic antimicrobial compounds. journal of ornamental plants, 8(2):87-99.

Reddy, T.; Nagarajaiah, C. and Raju, B. (1988). Silver nitrate pulsing of cut Queen Elizabeth rose stems to increase vase life. Hort. Absts., 9, 360.

Rogers, M.N. (1973). An historical and critical review of postharvest physiology research o cut flowers. HortScience, 8(3):189-194.

Snedecor, G.W. and Cochran, W. (1989). Statistical Methods, $8^{\text {th }}$ Edition. Iowa State University Press, Ames., 503 p.
Tiwari, A.K. and Singh, R. (2002). Effect of antimicrobial compounds on the postharvest life of rose. Applied Horticulture, 4:52-53.

Torre, S.; Borochov, A. and Haleavy, A.H.H. (2002). Calcium regulation of senescence in rose petals. Physiologia Plantarum, 107(2):214-219.

Vahdati, N.M.; Tehranifar, A.; Bayat, H. and Selahvarzi, Y. (2012). Salicylic and citric acid treatments improve the vase life of cut chrysanthemum flowers. J. Agric. Sci. Technol., 14:879-887.

Van Doorn, W.G. (1997). Water relations of cut flowers. Hort. Rev., 53(18):1-85.

Veen, H. and Van de Geijn, S.C. (1978). Mobility of ionic form of silver as related to longevity of cut carnations. Planta, 145:93-96.

Wellburn, A.R. (1994). The spectral determination of chlorophylls a and $\mathrm{b}$, as well as total carotenoids, using various solvents with spectrophotometers of different resolution. Journal of Plant Physiology, 144(3):307-313.

\section{تاثير بعض المبيدات الحيوية على فترة بقاء أزهار القرنفل المقطوفة في الفازة}

$$
\begin{aligned}
& \text { أماني إسماعيل آدم ومنى بدر الدين الديب } \\
& \text { فرع بحوث الزهور ونباتات الزينة وتنسيق الحدائق بأنطونيادس، معهد بحوث البين البساتين، مركز البحوث الزر اعية، } \\
& \text { الأسكندرية، مصر بانيان مصر }
\end{aligned}
$$

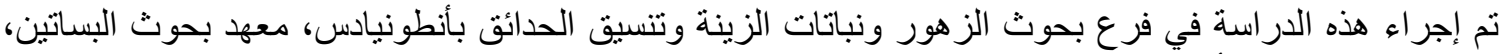

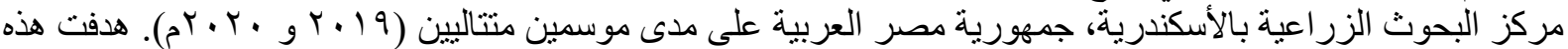

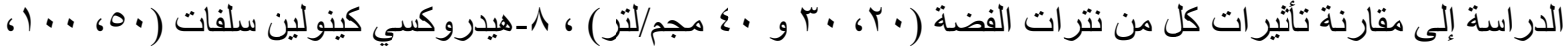

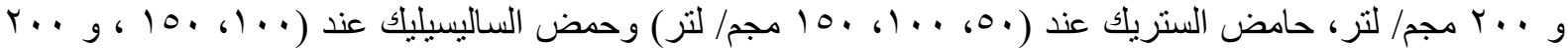

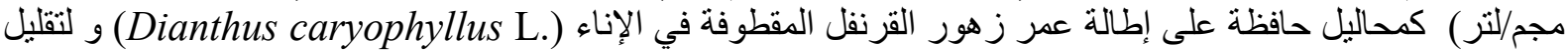

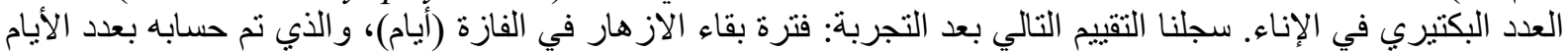

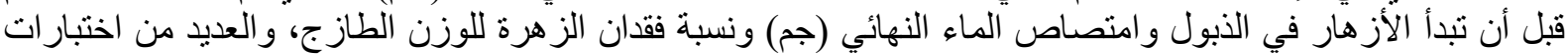

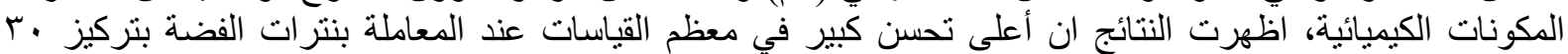

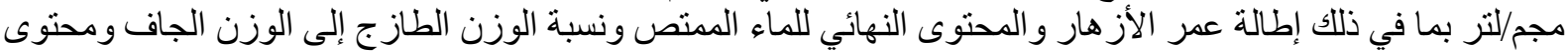

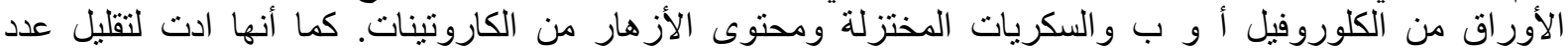

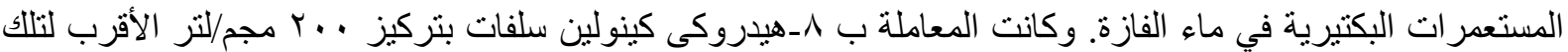

